INDEPENDENT JOURNAL OF MANAGEMENT \& PRODUCTION (IJM\&P)

http://www.ijmp.jor.br

v. 7, n. 2, April - June 2016

ISSN: 2236-269X

DOI: 10.14807/ijmp.v7i2.404

\title{
AN EXPLORATORY STUDY OF BRAND EQUITY OF A COMMERCIAL BANK IN VADODARA, INDIA
}

Ashutosh Anil Sandhe TeamLease Skills University, India E-mail: ashutoshsandhe@yahoo.com

Submission: 09/11/2015

Revision: 21/11/2015

ABSTRACT

Accept: 27/11/2015

Banks play an important role in circulation of money in a country. With increased competition in banking sector, marketing of a bank becomes important and marketing strategies an essential for every bank. A research was carried out in Vadodara, India to identify the brand equity of one of the major private sector banks. Brand equity was studied by applying Keller's Brand Resonance Model. It was found in the study that brand feelings are the most important component of brand equity in Vadodara and brand salience the least important one. Also, all four components i.e. brand salience, brand performance, brand judgements and brand feelings were positively correlated to each other and also brand resonance. Regression model was applied to estimate brand resonance and the impact of four components on it.

Keywords: Brand Salience, Brand Performance, Brand Judgements, Brand Feelings, Brand Resonance, Brand Equity 


\section{INTRODUCTION}

For every organization, brand name has become very important in today's competitive era. A brand can simply be termed as a unique identity of a product or service offered by a particular organization. It enables both, the organization as well as the consumer to differentiate between similar products or services offered by competitors.

However, in light of competition, brand name is not just a unique identity. It has assumed a broader meaning. According to Keller, a brand, which is powerful, will be able to create a meaningful image in consumers' mind as compared to a weaker brand. A strong brand image and powerful reputation will be able to enhance the differentiation capability of a product or service and it will have a positive influence on the buying behavior of consumers (GORDON et al., 1993; MCENALLY; CHERNATONY, 1999).

Further, branding is important for all kinds of products and services. According to Mudambi, branding of an offering in consumer markets could result in enhancing the financial performance and competitive position of a firm (KERRI-ANN, et al., 2008).

Brand can be defined as a bundle of functional, economic and psychological benefits for the end user (AMBLER, 1995). According to the American Marketing Association (AMA), brand is a name, term, sign, symbol, or design, or a combination of them which is intended to identify the goods or services of one seller or a group of sellers and to differentiate them from those of competitors.

Brand equity refers to the marketing effects and outcomes that build up to a good or service with its brand name (VIKASGAUTAM, 2012). The power of brand equity can be seen in the form of consumers' willingness to pay a premium price for a preferred brand in comparison to others. Not only that, brand equity is reflected in the way consumers recommend it to their peers. (HUTTON, 1997).

In this research, an attempt was made to study and analyze the brand equity of a leading private sector bank in Vadodara. For this purpose, the Brand Resonance Model propounded by Keller was used. Using the components in the model, a correlation between components and brand resonance was found out. Data was collected from customers of the bank in Vadodara in the form of a structured 
DOI: 10.14807/ijmp.v7i2.404

questionnaire, which was then analyzed using SPSS (SPSS stands for Statistical Package for Social Sciences. It is a software which carries out the data analysis. It is a worksheet where all the statistical tests are done. IBM is the owner of the software).

In this research, primary data collected in the form of questionnaires was encoded in SPSS and from that statistical results like Cronbach Alpha, Chi-square, mean, correlation, regression was carried out.

\section{LITERATURE REVIEW}

Kevin Lane Keller in the research titled "Building Customer - Based Brand Equity" suggested that creating brand resonance needs a careful sequencing of brand building efforts by a firm. Keller put forward the concept of customer-based brand equity (CBBE) which suggested that brand knowledge makes consumers' response to marketing of the brand differently (KELLER, 1993).

\subsection{Kerri-Ann L. Kuhn, Frank Alpert, Nigel K. LI. Pope}

In this study, researchers highlighted the suitability and limitations of Keller (1993), customer-based brand equity model and check whether it could be applied in a business-to-business (B2B) market scenario. It was found that amongst institutional buyers there is a greater emphasis on the selling organization, including its corporate brand, credibility and staff, than on individual brands and their associated dimensions (KERRI-ANN, et al., 2008).

\subsection{Vikas Gautam, Mukund Kumar}

Researchers used Keller's Customer Based Brand Equity Model to study and analyze the brand equity of banks. Exploratory factor analysis was carried out to reduce the total number of items to a small number of underlying factors, and the results produced six factors, which were brand resonance; brand judgements; brand feelings; brand performance; brand imagery; brand salience.

The alpha coefficients of the reliability test were found to be ranging from 0.781 to 0.912 for all of the brand equity constructs individually, and for the entire scale, the value of alpha was found to be 0.837 . Correlation analysis was performed to find out relationships among various components of brand equity. From the findings of multiple regression analysis, it was clear that brand performance was the 
DOI: 10.14807/ijmp.v7i2.404

most important determinant of brand resonance, followed by brand feelings $(0.427)$ and brand judgements (0.306) (VIKASGAUTAM, 2012).

\subsection{PekkaTuominen}

The purpose of this study was to discuss the main issues encountered in managing brand equity. For this, the concept of brand equity was analyzed first. Then a comprehensive framework for managing brand equity was provided; and finally, ways to measure and leverage brand equity were distinguished by the authors (TUOMINEN, 1999).

\subsection{Nadia Farhana and Shohana Islam}

This research was carried out to evaluate the brand equity of banks in Bangladesh using Keller (1993) Brand Resonance Model. Random samples of 300 respondents were selected and information collected from them in the form of a structured questionnaire.

The research found that when customers are emotionally attached to a brand (brand feeling), they go on to create strong association with the brand. The quality of the services of a brand, its credibility, and its presence in the choice set of customers (together what is called Brand Judgment) also lead to customers' strong association with a brand.

On the other hand, some of the building blocks of the CBBE model were not found to be strongly contributing for the creation of brand association in the banking sector of Bangladesh. Brand recognition and brand recall (together called brand salience) were found not contributing significantly in creating strong association with the brand. Banking institutions may place less emphasis on them in creating brand awareness (MACINNIS; PARK; PRIESTER, 2009).

\subsection{Maclnnis, Park and Priester}

The domain of brand relationships is extremely complex. There are numerous types of brand relationships and multiple dimensions that characterize them. They involve varying types and intensities of emotions and normative processes. They vary in the motivations that drive them, the strength of the connection bonding the consumer with the brand, and the role of various meaning makers in creating, establishing, and expanding the brand's relationship to the self. Moreover, the 
DOI: 10.14807/ijmp.v7i2.404

psychological and behavioral outcomes of brand relationships are also numerous and complex.

\subsection{Swaminathan, Page Gurhan-Canli}

As we know the development of brand is the process which includes identity, meaning, response and relationship but if helps to attachment of consumers towards brand (KELLER, 2001).

The studies on brand relationship reveal that strong brand relationship is important factor for promoting tolerance in the face of negative brand information. Past research shows that if marketers wants to convert negative brand information to positive then consumer brand relationship is the best competent to transform this information (SWAMINATHAN; GURHAN-CANLI, 2007).

\subsection{Fournier}

According to Fournier (1998) consumer viewed brand as a relationship partner. There is different way to achieve this understanding of consumers about brand, one way is to brand are animated, humanized or personalized. She also explained the brand animated process through which the spirit of past or present other, by using brand-person associations, and through a complete anthropomorphization of the brand. Brand relationship also depends on the consumers lived experience, this define level of brand relationship. These relationships offer meanings to the consumer, some being functional and utilitarian, while others are psychological or emotional.

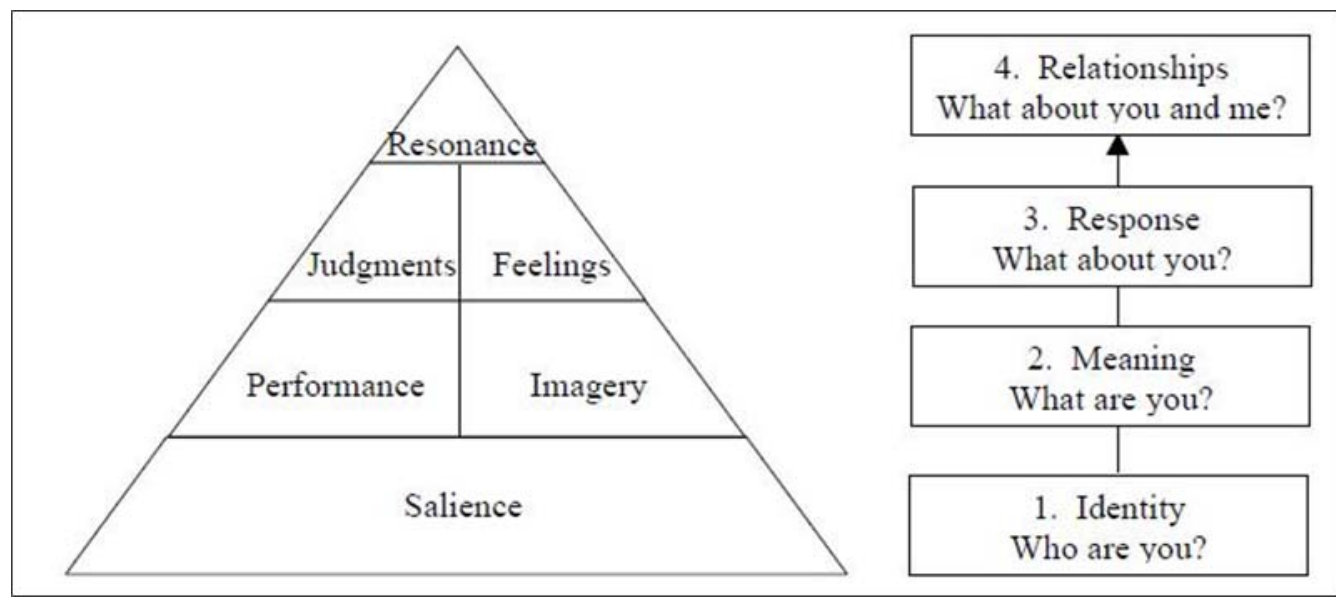

Figure 1: Theoretical Construct of Customer - Based Brand Equity Model by Keller. 
DOI: 10.14807/ijmp.v7i2.404

\subsubsection{Brand Salience}

Achieving the right brand identity involves creating brand salience. Brand salience relates to aspects of customer awareness of the brand. How easily and how often is the brand evoked under various situations or circumstances? To what extent is the brand top-of-the-mind and easily recalled or recognized? What types of cues or reminders are necessary? How pervasive is brand awareness (KELLER, 2001).

\subsubsection{Brand Performance}

The product itself is at the heart of brand equity, as it is the primary influence of what consumers experience with brand, what they hear about a brand from others and what the firm can tell customers about the brand in their communications. To create brand loyalty and resonance, consumers' experience with the product must at least meet, if not actually surpass, their expectations (KELLER, 2001).

\subsubsection{Brand Imagery}

Brand imagery deals with the extrinsic properties of the product or service, including the ways in which the brand attempts to meet customers' psychological or social needs (KELLER, 2001).

\subsubsection{Brand Feelings}

They are customers' emotional responses and reactions with respect to the brand. Brand feelings also relate to the social currency evoked by the brand (KELLER, 2001).

\subsubsection{Brand Resonance}

The final step of the model, brand relationships focus upon the ultimate relationship and level of identification that the customer has with the brand. Brand resonance refers to the nature of the relationship that customers have with brand and the extent to which they feel they are "in synch" with the brand (KELLER, 2001).

Resonance is the intensity of customers' psychological bond with the brand and the level of activity it engenders (KOTLER, 2014).

The brand resonance model as put forward by Keller suggests that brand building is a series of steps starting from brand salience and passing through brand performance, brand judgements and brand feelings. The result is brand resonance 
DOI: 10.14807/ijmp.v7i2.404

or brand loyalty. Thus, all the steps are inter-related. In this research, analyses was conducted to study the relationship between these steps.

\section{OBJECTIVES OF THE RESEARCH}

- To study and analyze brand equity of banks in Vadodara.

- To study, analyze and understand the determinants of brand equity of banks in Vadodara.

- To analyze the relationship between various components of brand equity for banks in Vadodara.

- To understand the effect of brand salience, brand performance, brand judgment and brand feelings on brand resonance for banks in Vadodara.

\section{RESEARCH METHODOLOGY}

The research design of this study was descriptive and exploratory. A sample size of 335 customers of a leading private sector bank in Vadodara was chosen. Stratified random sampling technique was used to collect data wherein, occupation was taken as strata. Service, business, profession and others, which comprised students, were selected as the strata for the study.

The questionnaire was divided into 6 parts. First part of the questionnaire was to collect the demographic information of the respondents. Second part had questions regarding brand salience. Third part of the questionnaire was to collect information about brand performance whereas, fourth part covered questions pertaining to brand judgement. Fifth part of the questionnaire contained questions on brand feelings and last part was to study brand resonance for banks.

All questions from part two to part six were on a five point Likert scale where respondents were asked to rate the statements as "strongly agree", "agree", "can't say", "disagree" and "strongly disagree". (Instead of getting answer in directly "yes" or "no", respondents are asked to give their opinion on some statements given in the questionnaire in the form of "agreement" or "disagreement").

After collecting the data, analysis was done using, SPSS and hypothesis were tested. For the purpose of confidentiality, the name of the bank has not been 
INDEPENDENT JOURNAL OF MANAGEMENT \& PRODUCTION (IJM\&P)

http://www.ijmp.jor.br

v. 7, n. 2, April - June 2016

ISSN: 2236-269X

DOI: 10.14807/ijmp.v7i2.404

revealed in the study and is referred to as "Bank" in the entire research paper. The data collected for this research was found to be reliable as mentioned in Table No.1.

The Cronbach alpha for all the factors determining brand resonance was found to be greater than 0.70 and overall alpha was 0.896 . Thus, further analysis of the data would give reliable conclusions.

Table 1: Showing Reliability Statistics (Cronbach Alpha)

\begin{tabular}{|l|r|}
\hline \multicolumn{1}{|c|}{ Factor } & \multicolumn{1}{c|}{ Alpha } \\
\hline Brand Salience & 0.732 \\
\hline Brand Performance & 0.849 \\
\hline Brand Judgement & 0.861 \\
\hline Brand Feelings & 0.777 \\
\hline Brand Resonance & 0.898 \\
\hline Overall & $\mathbf{0 . 8 9 6}$ \\
\hline
\end{tabular}

\subsection{Hypotheses}

H1: There is no significant brand resonance for the Bank in Vadodara

H2: There is no significant relationship between brand salience, brand performance, brand judgment, brand feelings and brand resonance for the Bank in Vadodara.

H3: There is no significant impact of brand salience, brand performance, brand judgment and brand feelings on brand resonance for the Bank in Vadodara.

\subsection{Data Analysis}

Table 2: Table Showing Demographic Features of Respondents in Vadodara.

\begin{tabular}{|c|c|c|c|c|c|c|c|}
\hline Feature & & $\mathbf{N}$ & $\%$ & Feature & & $\mathbf{N}$ & $\%$ \\
\hline \multirow{4}{*}{ Age } & $20-30$ & 102 & 30.45 & \multirow{6}{*}{ Income } & $<1 \mathrm{Lac}$ & 48 & 14.33 \\
\hline & $30-40$ & 128 & 38.21 & & $1.01-2.00$ & 34 & 10.15 \\
\hline & $41-50$ & 79 & 23.58 & & 2.01-3.00 & 52 & 15.52 \\
\hline & Above 50 & 26 & 7.76 & & $3.01-4.00$ & 47 & 14.03 \\
\hline \multicolumn{2}{|c|}{ Total } & 335 & 100 & & $4.01-5.00$ & 62 & 18.51 \\
\hline \multirow{4}{*}{ Occupation } & Service & 119 & 35.52 & & Above 5 & 92 & 27.46 \\
\hline & Business & 97 & 28.96 & \multicolumn{2}{|r|}{ Total } & 335 & 100 \\
\hline & Profession & 86 & 25.67 & \multirow{2}{*}{ Maritals } & Married & 263 & 78.51 \\
\hline & Others & 33 & 9.85 & & Unmarried & 72 & 21.49 \\
\hline \multicolumn{2}{|c|}{ Total } & 335 & 100 & \multicolumn{2}{|r|}{ Total } & 335 & 100 \\
\hline \multirow{2}{*}{ Gender } & Male & 218 & 65.07 & \multirow{3}{*}{ Education } & Graduate & 100 & 29.85 \\
\hline & Female & 117 & 34.93 & & Post Graduate & 134 & 40.00 \\
\hline \multicolumn{2}{|c|}{ Total } & 335 & 100 & & Professional & 101 & 30.15 \\
\hline & & & & \multicolumn{2}{|r|}{ Total } & 335 & 100 \\
\hline
\end{tabular}


DOI: 10.14807/ijmp.v7i2.404

As can be seen in Table No.2 above, $35.52 \%$ respondents' occupation was service, $28.96 \%$ respondents were businessmen and $25.67 \%$ respondents were professionals. $9.85 \%$ respondents belonged to student category, which is shown above as "others". Other characteristics of the respondents can be observed in the above table.

H1: There is no significant brand resonance for the Bank in Vadodara

Table 3: Table Showing Descriptive Statistics for Brand Resonance of the Bank in Vadodara

\begin{tabular}{|l|r|r|r|r|l|}
\hline Factor & N & \multicolumn{1}{|c|}{ Mean } & \multicolumn{1}{c|}{ s.d. } & Chi-Square & \multicolumn{1}{l|}{ Sig } \\
\hline Salience & 335 & 4.07 & 0.568 & 56.21 & 0.000 \\
\hline Performance & 335 & 3.92 & 0.857 & 29.71 & 0.002 \\
\hline Judgment & 335 & 3.85 & 0.741 & 30.86 & 0.021 \\
\hline Feelings & 335 & 3.57 & 0.767 & 43.00 & 0.000 \\
\hline Resonance & 335 & 3.45 & 1.058 & 29.60 & 0.003 \\
\hline
\end{tabular}

According to the Brand Resonance Model put forward by Keller, brand resonance of a product or service is high if the components or bases of brand resonance show significant degree of strength. In the present study, it can be seen that all factors affecting brand resonance like salience, performance, judgment and feelings have a mean value of above 3.45 out of 5 suggesting reasonable levels.

From among all the bases, brand salience has the highest mean of 4.07 while brand feelings have the least mean value of 3.57. Since, all the bases have shown high mean values, brand resonance for the Bank was found to be high in Vadodara with mean value of 3.45. Further, to strengthen the argument, chi square values and significance of all the variables were less than 0.05 . Thus, from the data analysis it is clear that there is significant brand resonance for the Bank in Vadodara. Thus, the null hypothesis is rejected and alternate hypothesis is accepted.

H2: There is no significant relationship between brand salience, brand performance, brand judgment, brand feelings and brand resonance for the Bank in Vadodara.

Based on the previous hypothesis, it was established that there is significant brand resonance for the Bank in Vadodara. Based on that conclusion, further analysis could be carried out. Therefore, an attempt was made to study the relationship between the variables of brand resonance. For this purpose, correlation analysis was carried out which is shown in Table No.4 below- 
DOI: 10.14807/ijmp.v7i2.404

Table 4: Table Showing Pearson's Correlation between Factors Affecting Brand Resonance for Bank in Vadodara

\begin{tabular}{|l|r|r|r|r|r|}
\hline & \multicolumn{1}{|c|}{$\begin{array}{c}\text { Salience } \\
\text { (BS) }\end{array}$} & \multicolumn{1}{c|}{$\begin{array}{c}\text { Performance } \\
(\mathrm{BP})\end{array}$} & \multicolumn{1}{c|}{$\begin{array}{c}\text { Judgement } \\
(\mathrm{BJ})\end{array}$} & \multicolumn{1}{c|}{$\begin{array}{c}\text { Feelings } \\
(\mathrm{BF})\end{array}$} & \multicolumn{1}{c|}{$\begin{array}{c}\text { Resonance } \\
(\mathrm{BR})\end{array}$} \\
\hline Salience (BS) & 1 & $.649^{* *}$ & $.752^{* *}$ & $.640^{* *}$ & $.589^{* *}$ \\
Performance (BP) & $.649^{* *}$ & 1 & $.776^{* *}$ & $.696^{* *}$ & $.719^{* *}$ \\
Judgment (BJ) & $.752^{* *}$ & $.776^{* *}$ & 1 & $.782^{* *}$ & $.690^{* *}$ \\
Feelings (BF) & $.640^{* *}$ & $.696^{* *}$ & $.782^{* *}$ & 1 & $.861^{* *}$ \\
Resonance (BR) & $.589^{* *}$ & $.719^{* *}$ & $.690^{* *}$ & $.861^{* *}$ & 1 \\
\hline
\end{tabular}

From the above Table No.4 it is clear that there was a significant level of correlation between the variables determining brand resonance for the Bank in Vadodara. The strongest correlation was found between brand feelings and brand resonance $(0.861)$, while the weakest correlation was found between brand salience and brand resonance (0.589).

This indicates that consumers prefer a bank not simply on the basis of its identity and awareness (salience), but on the basis of their own feelings towards the bank in Vadodara. A value of 0.589 represents moderate level of correlation. Thus, brand awareness is an important factor determining brand resonance, but it is not the strongest variable determining brand resonance.

The strongest variable is brand feelings. In other words, brand feelings have the maximum impact on brand resonance for the Bank in Vadodara. Brand feelings refer to the emotional connect between customers and their banks. Brand feelings include warmth, fun, excitement, security, social approval and self- respect (KELLER, 2001).

Hence, it could be said that customers of the bank have a positive brand feeling for it in Vadodara. Similarly, all other variables like brand performance and judgment also had significant levels of correlations as can be seen in the above Table No.4. An important facet that can be seen in the above table is that not only are the variables related to brand resonance, but there is a significant level of correlation between the variables themselves.

Thus, as suggested by Keller, these variables are the steps to brand building which is resonance. Thus, brand salience, brand performance, brand judgment and brand feelings lead to brand resonance. This is clear from the diagram below- 


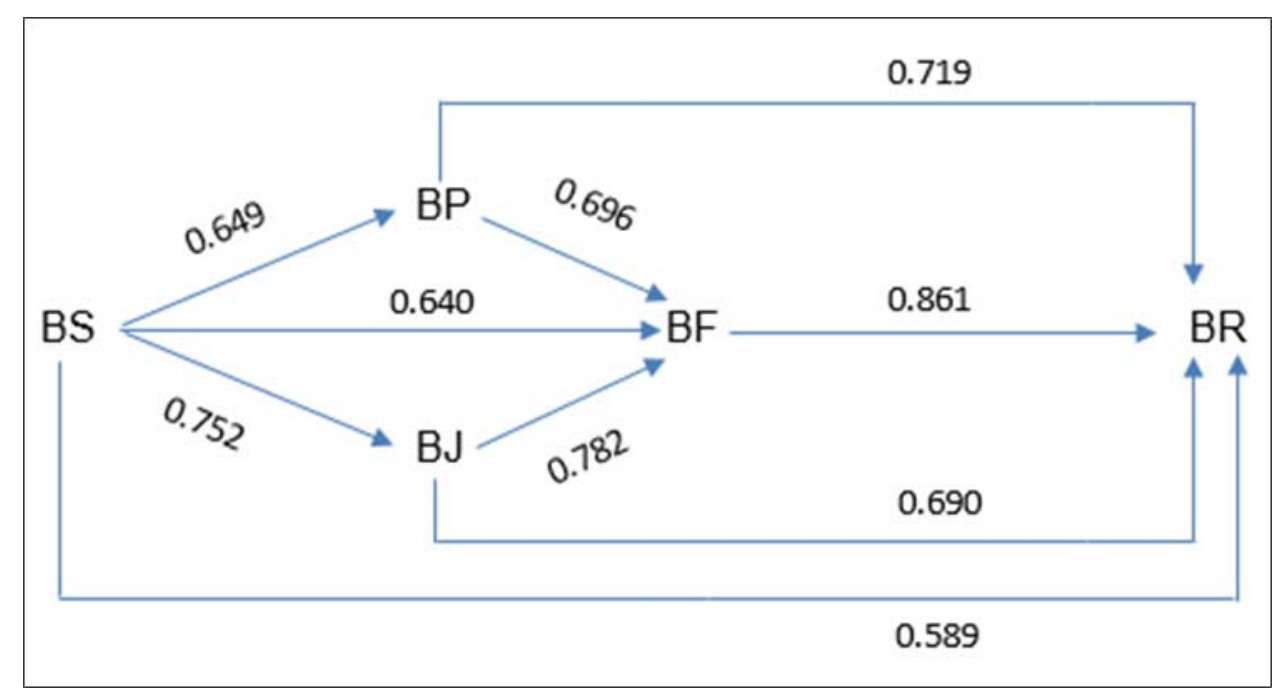

Figure 2: Correlation between Variables affecting Brand Resonance for the Bank in Vadodara

Further, as stated in the model of brand resonance, there exists a positive and significant correlation between all the variables as provided in the above figure 1 . The strongest correlation was found between brand judgement and brand feelings (0.782) while the lowest correlation was found between brand salience and brand feelings (0.640). However, the data showed that there was moderate to high correlation between all the factors and that led to a high level of brand resonance.

Thus, on the basis of correlation analysis and the results obtained, it can be said that the null hypothesis is rejected and alternate hypothesis is accepted. Thus, there was significant relation between the variables determining brand resonance for the Bank in Vadodara.

H3: There is no significant impact of brand salience, brand performance, brand judgment and brand feelings on brand resonance for the Bank in Vadodara.

Having established significant between variables determining brand resonance for the bank in Vadodara, the next step was to attempt to predict the effect of changes in variables on brand resonance for the bank in Vadodara. For this purpose, regression was used. For the purpose of developing regression equation, four components of brand resonance, i.e. brand salience, brand performance, brand judgement and brand feelings were considered independent variables and brand resonance was taken as dependent variable. Accordingly, the following Regression Model was used in this study -

$$
Y 1=\beta 0+\beta 1 X 1 i+\beta 2 X 2 i+\beta 3 X 3 i+\beta 4 X 4 i+\mu i,
$$


DOI: 10.14807/ijmp.v7i2.404

In this equation, $i$ is the sample size from 1 to $335, Y$ is the Brand Resonance, $\mathrm{X} 1$ is Brand Salience, $\mathrm{X} 2$ is Brand Performance, $\mathrm{X} 3$ is Brand Judgement, $\mathrm{X} 4$ is the Brand Feelings, and $\mu$ is the random error term. The results of regression analysis are shown in Table No.5.

Table 5: Table Showing the Effect of Factors on Brand Resonance for the Bank in Vadodara

\begin{tabular}{|l|r|r|r|r|}
\hline Independent Variables & \multicolumn{1}{c|}{$\begin{array}{c}\text { Unstandard } \\
\text { Beta }\end{array}$} & $\begin{array}{c}\text { Standard } \\
\text { Beta }\end{array}$ & \multicolumn{1}{c|}{$\mathbf{t}$} & \multicolumn{1}{c|}{$\begin{array}{c}\text { sig. } \\
\text { value }\end{array}$} \\
\hline Constant & -1.074 & & 2.619 & 0.011 \\
\hline Brand Salience & 0.052 & 0.028 & 0.336 & 0.738 \\
\hline Brand Performance & 0.357 & 0.289 & 3.291 & 0.001 \\
\hline Brand Judgement & 0.210 & 0.147 & 1.331 & 0.187 \\
\hline Brand Feelings & 1.044 & 0.757 & 8.556 & 0.000 \\
\hline
\end{tabular}

Table 6: Model Summary

\begin{tabular}{|c|c|c|c|c|}
\hline R & R Square & Adjusted R Square & F Value & Sig. Value \\
\hline $0.880^{\mathrm{a}}$ & 0.774 & 0.763 & 67.728 & 0.000 \\
\hline
\end{tabular}

a. Predictors: (Constant), Feelings, Salience, Performance, Judgement

On the basis of data analysis and above Table No.5, following estimated regression equation was obtained-

Brand Resonance $=-1.074+1.044$ Brand Feelings

+0.357 Brand Performance

+0.210 Brand Judgement

+0.052 Brand Salience

Overall R2 for the equation was found to be 0.774 with $F$ Value significant at $1 \%$ level of significance. Thus, from the data analysis and the ensuing regression equation, it was observed that the component Brand Feelings (1.044) emerged as the most important factor of brand equity followed by Brand Performance $(0.357)$ and Brand Judgement (0.210). Brand Salience (0.052) was the least important component in this research.

The results of the regression equation can be interpreted that more positive or favorable are the feelings towards the bank, higher will be the brand resonance among the customers. Hence, the bank under study should formulate a marketing strategy, which results into positive brand feelings in its customers. This positivity 
DOI: $10.14807 /$ ijmp.v7i2.404

could be brought through promotion activities or, more importantly through customer delight.

\section{FINDINGS}

The research conducted on a leading private sector bank in Vadodara revealed that brand resonance for the bank was found to be high (Mean $=3.45$ ) and significant $(p=0.003)$. All the four components of brand resonance were also found to be high and significant. Thus, the bank's brand equity was found to be high in Vadodara. Further analysis of the data in the form of correlation analysis showed that all the components leading to brand resonance were positively and significantly correlated with each other.

Thus, the model was successfully tested in Vadodara. Out of all the components, Brand Feelings (0.861) showed the highest correlation with Brand Resonance, while Brand Salience (0.589) showed the least correlation with Brand Resonance. Based on the results of correlation analysis, regression equation was formed to find estimated brand resonance. It was found that the regression equation was significant with $R^{2}=0.774$ at $1 \%$ significance level. Regression equation showed that brand feelings would have the most effect on brand resonance in Vadodara. So, higher the brand feeling, higher would be the brand resonance.

\section{REFERENCES}

AAKER, D. A. (1991), Managing Brand Equity: Capitalizing on the Value of a Brand Name, Free Press, New York.

AMBLER, T., (1995), Building Brand Relationships, Financial Times Mastering Management Series, v. Dec, n. 6, p. 8-11.

FARHANA, N.; ISLAM, S. (2012), Analyzing The Brand Equity and Resonance of Banking Services: Bangladeshi Consumer Perspective, World Review of Business Research, v. 2, n. 4, p. 148-163.

FOURNIER, S. (1998, March), Consumers and Their Brands: Developing Relationship Theory in Consumer Research, Journal of Consumer Research, $p$. 343-373.

GORDON, G. L.; CALANTONE, R. J.; DI BENEDETTO, A. C. (1993), Brand Equity in the Business-to-Business Sector: An Exploratory Study, Journal of Product and Brand Management, v. 2, n. 3, p. 4-16.

HUTTON, J. G. (1997), A Study of Brand Equity in an Organizational-Buying Context, Journal of Product and Brand Management, v. 6, n. 6, p. 428-439. 
DOI: 10.14807/ijmp.v7i2.404

KELLER, K. L., (1993), Conceptualizing, Measuring and Managing Customer-Based Brand Equity, Journal of Marketing, v. 57, n. 1, p. 1-22.

KELLER, K. L., (2001), Building Customer-Based Brand Equity, Marketing Management, v. 10, n. 2, p. 14-19.

KELLER, K. L. (2003), Strategic Brand Management: Building, Measuring and Managing Brand Equity, 2nd Ed, Prentice Hall, New Jersey.

KERRI-ANN L. K.; ALPERT, F.; NIGEL K.; POPE, L. (2008), An Application of Keller's Brand Equity Model in a B2B Context, Qualitative Market Research: An International Journal, v. 11 n. 1 , p. $40-58$

KOTLER, P., et al, (2014), Marketing Management: A South Asian Perspective, New Delhi, Pearson, p. 268-269

MACINNIS, D. J.; PARK, C. W.; PRIESTER, J. R. (2009), Handbook of Brand Relationships. Armonk: M. E. Sharpe, New York.

MCENALLY, M. R.; DE CHERNATONY, L., (1999), The Evolving Nature of Branding: Consumer and Managerial Considerations, Academy of Marketing Science Review, v. 2, p. 1.

SWAMINATHAN, V.; PAGE, K. L.; GURHAN-CANLI, Z. (2007), My Brand or Our Brand: The Effects of Brand Relationship Dimensions and Self- Construal on Brand Evaluations, Journal of Consumer Research, v. 34, p. 248-258.

TUOMINEN, P. (1999), Managing Brand Equity, The Finnish Journal of Business Economics, v. 1, p. 65-100.

VIKASGAUTAM, M. K. (2012), An Empirical Investigation to Analyze the Brand Equity and Resonance of Banking Services: Evidence from India, Management, v. 7 , n. 1, p. 3-16. 